\title{
Insulin-like growth factor-binding protein-3 protease activity in Snell normal and Pit-1 deficient dwarf mice
}

\author{
J A Koedam, C M Hoogerbrugge and S C van Buul-Offers
}

Department of Pediatrics, Wilhelmina Children's Hospital, Utrecht University, Utrecht, The Netherlands

(Requests for offprints should be addressed to J A Koedam, Department of Pediatrics, Wilhelmina Children's Hospital, Utrecht University, PO Box 18009, 3501 CA Utrecht, The Netherlands)

\begin{abstract}
Partial proteolysis of insulin-like growth factor-binding protein-3 (IGFBP-3) lowers its affinity for IGFs. Presumably, this leads to destabilization of the ternary IGFIGFBP-3-acid-labile subunit complex in the circulation and an increased bioavailability of IGFs. We investigated the effect of $\mathrm{GH}$ on IGFBP-3 proteolysis by comparing serum from normal mice and $\mathrm{GH}$-deficient dwarf mice. While normal mouse serum degraded ${ }^{125}$ I-IGFBP-3, this activity declined with age. In contrast, serum from dwarf mice displayed strong proteolytic activity at all ages tested (up to 10 weeks). In dwarf mice of 4 weeks and older, this activity could not be inhibited by EDTA and 1,10phenanthroline, indicating the presence of a divalent
\end{abstract}

cation-independent protease. Prolonged treatment with GH (4 weeks) did not decrease the overall potency of the serum to degrade IGFBP-3, but partially restored the ability of EDTA to inhibit IGFBP-3 protease activity. GH deficiency therefore appears to induce a new kind of IGFBP-3 protease. Similarly, serum from hypophysectomized rats displayed enhanced IGFBP-3 protease activity compared with control rat serum. These results suggest that a protease induced under conditions of severe GH deficiency may contribute to making IGFs optimally available to the tissues.

Journal of Endocrinology (1998) 157, 295-303

\section{Introduction}

The actions of the insulin-like growth factors IGF-I and IGF-II are modulated by the high affinity IGF-binding proteins (IGFBPs), a family of six structurally related proteins (Shimasaki \& Ling 1991, Jones \& Clemmons 1995). IGFBP-3 is the most abundant carrier protein of the IGFs in the circulation. Together with IGF and an $85 \mathrm{kDa}$ acid-labile subunit (ALS) it forms a $150 \mathrm{kDa}$ ternary complex which protects IGF against rapid degradation and clearance from the circulation (Baxter 1994). In addition, IGFBP-3 sequesters the IGFs away from their receptors, thereby limiting their biological activity.

IGFBP-3, as well as IGF-I and ALS, are regulated by growth hormone $(\mathrm{GH})$. Thus, IGFBP-3 levels are decreased in growth hormone deficiency (GHD) and increased in acromegaly (Baxter \& Martin 1986, Blum et al. 1990). In GHD dwarf rats and hypophysectomized (hypox) rats, GH induces IGFBP-3 and restores the $150 \mathrm{kDa}$ ternary complex (Gargosky et al. 1994, Fielder et al. 1996).

Another mechanism by which the inhibitory activity of IGFBP-3 can be regulated is through limited proteolysis. This modulation of IGFBP-3 occurs during pregnancy in humans (Giudice et al. 1990, Hossenlopp et al. 1990), rats (Davenport et al. 1990) and mice (Fielder et al. 1990). The generated fragments bind IGFs with lower affinity com- pared with intact IGFBP-3, resulting in an increased bioavailability of IGF (Blat et al. 1994). Increased proteolysis of IGFBP-3 has also been observed in severe illness (Davies et al. 1991), during postoperative stress (Cwyfan Hughes et al. 1992, Davenport et al. 1992a), in malignancies (Coulson et al. 1991, Muller et al. 1994) and in diabetes mellitus (Bang et al. 1994, Bereket et al. 1995).

It is not clear if proteolytic activity towards IGFBP-3 is regulated by GH. Binoux et al. (1993) reported that GHD patients have an increased proportion of proteolyzed IGFBP-3 in their circulation as compared with normals, while IGFBP-3 proteolysis was decreased in acromegalic subjects. Fielder et al. (1990), however, found that hypophysectomy had no effect on IGFBP-3 proteolysis by mouse serum. These results are in conflict with the findings of Rutishauer et al. (1993) who used hypox rats to show that GH induces an IGFBP-3 protease in serum.

Dwarfed Snell mice (genotype $d w / d w$ ) have a mutation in the gene for the Pit-1 transcription factor, which renders them deficient in $\mathrm{GH}$, prolactin, and thyroidstimulating hormone (Van Buul-Offers 1983, Li et al. 1990). The Snell heterozygous $(+/ d w)$ mice are phenotypically normal. We previously used these mice to study the effects of GH and IGFs on the serum levels of IGFBPs (Van Buul-Offers et al. 1994a,b). IGFBP-3 levels were almost undetectable in GHD dwarfs, but were 
significantly induced by treatment with GH and IGF-I and IGF-II, but not by thyroxine. We now report on the regulation of IGFBP-3 proteolysis in serum of Snell normal and dwarf mice.

\section{Materials and Methods}

\section{Materials}

BSA, Triton X-100, aprotinin, phenylmethylsulfonyl fluoride (PMSF), 1,10-phenanthroline, and 2-mercaptoethanol were from Sigma Chemical Co., St Louis, MO, USA.

Human GH was from Kabi-Pharmacia B.V., Woerden, The Netherlands (Genotropin) or from Novo Nordisk A/S, Bagsvaerd, Denmark (Norditropin). Solutions of GH were prepared in PBS, $\mathrm{pH} 7 \cdot 4$, containing $0 \cdot 2 \%$ BSA.

Recombinant human IGFBP-3 (E. coli derived, nonglycosylated, and $\mathrm{CHO}$ cell derived, glycosylated) were kindly provided by Drs Christopher A Maack, Jerome A Moore and Andreas Sommer of Celtrix Pharmaceuticals, Inc., Santa Clara, CA, USA (Sommer et al. 1991, Tressel et al. 1991). The proteins were iodinated with ${ }^{125} \mathrm{I}$ (Amersham International plc, Amersham, Bucks, UK) by the chloramine $\mathrm{T}$ method. Unbound radioactivity was removed on a PD-10 (Sephadex G-25) column (Pharmacia Biotech, Uppsala, Sweden). Specific activities for the radioiodinated IGFBP-3 ranged from 40 to $80 \mu \mathrm{Ci} / \mu \mathrm{g}$ protein.

\section{Serum samples}

Pooled serum of 20 healthy adults was used as a normal control. Serum from women in the 3rd trimester of pregnancy was used as a comparison for other serum samples, since it contains strong proteolytic activity for IGFBP-3 (Giudice et al. 1990, Hossenlopp et al. 1990, Lamson et al. 1991). Normal and dwarf Snell mice were bred and kept under standardized laboratory conditions, as described earlier (Van Buul-Offers et al. 1986). Dwarf mice between 6 and 8 weeks old were treated with $\mathrm{GH}$ $(16.6 \mathrm{mU} /$ day) or PBS for 4 weeks. Further details have been described previously (Van Buul-Offers et al. 1994b). Two hours after the last injection, the animals were killed by decapitation and blood was collected from the cervical stump and placed on ice. For each experiment, sera from five mice (males and females) were pooled. Sera of untreated mice were pooled from three to seven animals. Sera were frozen at $-20{ }^{\circ} \mathrm{C}$ until use.

Serum from normal and hypox male Wistar rats (5 weeks old) were obtained from Iffa Credo, L'Arbresle, France. Hypophysectomy was performed 3 days before serum collection.

\section{IGFBP-3 protease assay}

The presence of proteases in serum which can degrade IGFBP-3 was determined essentially as described by
Lamson et al. (1991). Serum $(2 \mu \mathrm{l})$ was mixed with 40000 c.p.m. ${ }^{125}$ I-IGFBP-3 (glycosylated or nonglycosylated as indicated in the text) in a total volume of $30 \mu \mathrm{l} 100 \mathrm{mM}$ Tris-HCl, pH 7.4, containing $0.5 \mathrm{mM}$ $\mathrm{CaCl}_{2}$ and $1 \%$ Triton X-100. Protease inhibitors were added as indicated in the text. The mixture was incubated for $16 \mathrm{~h}$ at $37^{\circ} \mathrm{C}$ and the reaction was stopped by the addition of $50 \mu \mathrm{l}$ SDS-sample buffer (containing 10\% 2 -mercaptoethanol) and boiling for $3 \mathrm{~min}$. The samples were electrophoresed on a $12 \%$ polyacrylamide gel, followed by staining in Coomassie Brilliant Blue and autoradiography using Fuji RX X-ray film. Quantitation of the gels was performed by phosphorimaging using a GS-363 Molecular Imager System together with Molecular Analyst software (Bio-Rad Laboratories, Inc., Hercules, CA, USA). The amount of proteolysis was expressed as the intensity in each lane which was associated with the degradation products of IGFBP-3 relative to the total intensity in the lane. The molecular masses of the fragments were calculated using broad-range molecular mass markers (Bio-Rad) as standards.

In a different approach, pooled normal human serum $(1.6 \mu \mathrm{l})$ was mixed with the serum to be tested $(0 \cdot 6 \mu \mathrm{l})$ in a final volume of $30 \mu \mathrm{l}$ of the same Tris- $\mathrm{HCl}$ buffer as above. After a $16 \mathrm{~h}$ incubation at $37^{\circ} \mathrm{C}$, the proteaseinduced disappearance of the intact IGFBP-3 doublet in the reference serum was monitored by Western ligand blotting.

\section{Western ligand blotting}

IGFBPs in serum were visualized by non-reducing SDSPAGE (7-15\% gradient gels) and electrotransfer to PVDF membranes (Immobilon-P, Millipore Corp., Bedford, MA, USA) followed by incubation with ${ }^{125}$ I-IGF-II. The procedure has been described in detail previously (Hossenlopp et al. 1986, Van Buul-Offers et al. 1994b).

\section{Statistical analysis}

Student's $t$-test was used to determine significant differences between two groups.

\section{Results}

Proteolysis of ${ }^{125}$ I-IGFBP-3 by various serum samples is presented in Fig. 1. On reducing SDS-PAGE, nonglycosylated IGFBP-3 migrated as a single band of $35 \mathrm{kDa}$ (Fig. 1A). Human non-pregnancy serum (standard pools) and serum from normal adult mice (FVB strain, 8 weeks old) displayed little proteolytic activity: $32 \cdot 9 \pm 7 \cdot 2 \%$ (mean \pm S.D., $n=4)$ and $39 \cdot 0 \%(n=2)$ were degraded by these sera respectively. Human pregnancy serum as well as serum from a normal mouse (FVB strain) at 3 weeks of pregnancy proteolyzed IGFBP-3 and generated a major fragment migrating at $18 \mathrm{kDa}$. Other bands with varying 


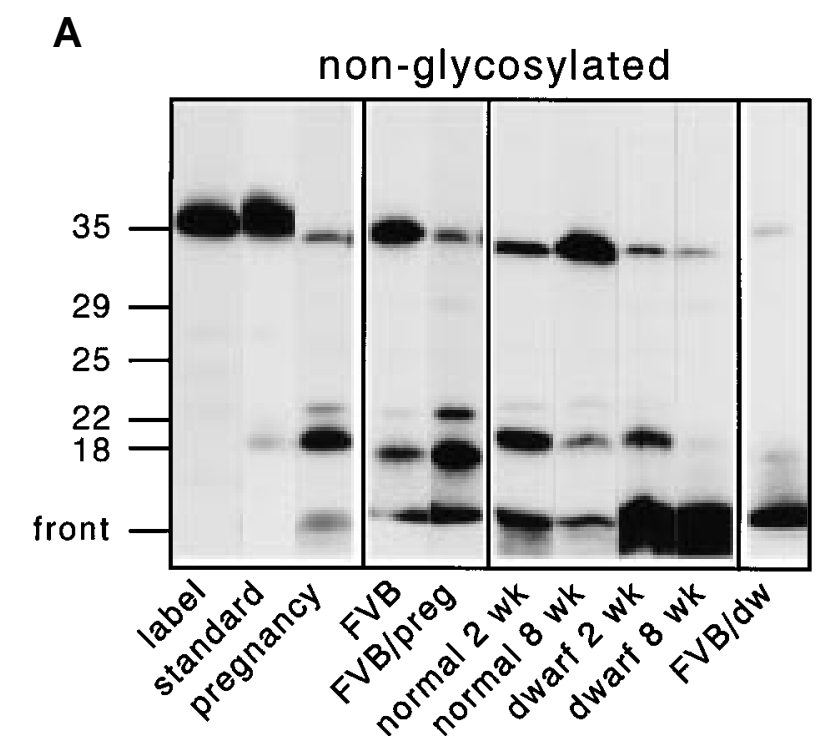

B
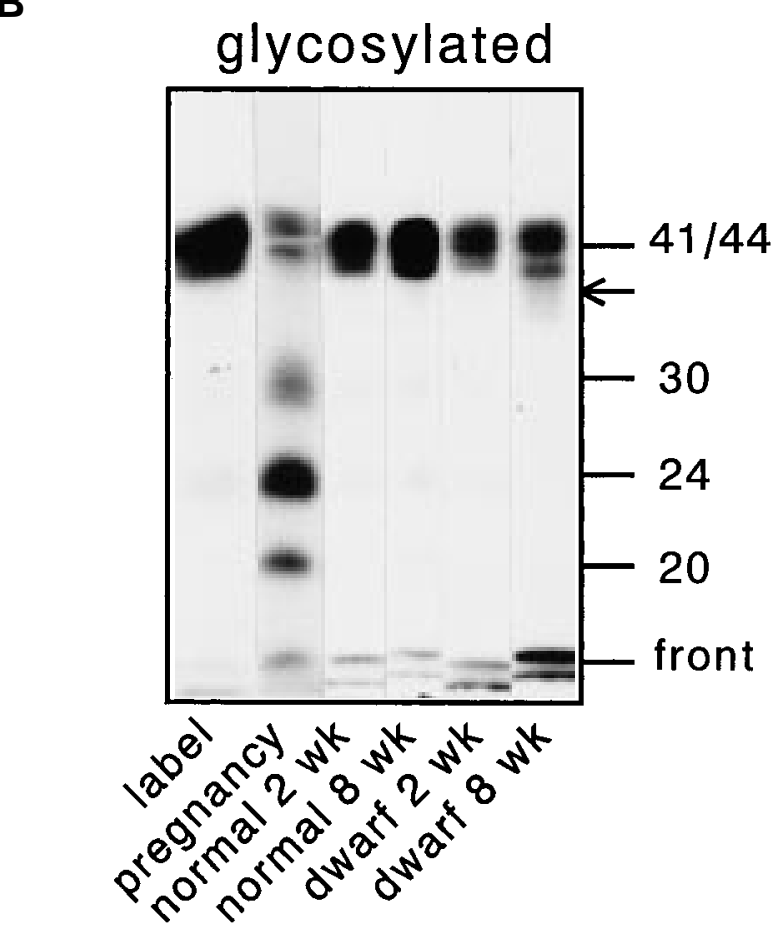

Figure 1 Proteolysis of IGFBP-3 by various sera. Non-glycosylated (A) or glycosylated (B) ${ }^{125}$ I-IGFBP-3 was incubated with $2 \mu$ l serum as detailed in Materials and Methods. Samples were electrophoresed on SDS gels under reducing conditions. Photographs show composites of autoradiograms of representative experiments. Molecular masses $(\mathrm{kDa})$ of the fragments are indicated. The arrow in (B) indicates the series of fragments which were unique for the degradation of glycosylated IGFBP-3 by serum from dwarf mice. Lanes represent sera from the following: standard, normal pool; pregnancy, human pregnancy (third trimester); FVB, 8-week-old FVB mouse; FVB/preg, FVB mouse at late pregnancy (21 days); normal, $+/ d w$ Snell mouse at 2 and 8 weeks old; dwarf, $d w / d w$ Snell mouse at 2 and 8 weeks old; FVB/dw, FVB intercrossed with dwarf at 8 weeks old.

intensities were observed at 29,25 and $22 \mathrm{kDa}$. Also smaller fragments of $<10 \mathrm{kDa}$ were prominent near or at the front of the gel. On a 10-20\% polyacrylamide gradient gel, these latter bands migrated well behind the dye front, indicating that they did not represent free radioiodine, but indeed were peptide fragments (result not shown). The total amount of proteolysis, both for the human and mouse pregnancy sera, was $88 \%$. Serum from 2 -week-old Snell normal mice contained an increased proteolytic activity compared with 8-week- old normal mice (from 36 to 68\% in this experiment). By comparison, serum from Snell dwarf mice displayed high protease activity at both ages (76 and $88 \%$ at 2 and 8 weeks respectively). Dwarf mice with an FVB genetic background (obtained by intercrossing Snell $d w / d w$ with FVB (Van Buul-Offers et al. 1995)) gave results identical to the Snell dwarfs. In contrast to the pregnancy sera and the normal 2-week-old mouse sera, the dwarf sera generated mostly the smaller $(<10 \mathrm{kDa})$ IGFBP-3 fragments.

Serum from Snell mice also proteolyzed glycosylated recombinant IGFBP-3, as is illustrated in Figs. $1 \mathrm{~B}$ and $4 \mathrm{~A}$. The effect (41 and 44\% proteolysis for dwarfs at 2 and 8 weeks old) was less prominent than with non-glycosylated
IGFBP-3, suggesting a protective effect by the sugar side chains. Human pregnancy serum generated fragments of 30,24 , and $20 \mathrm{kDa}$, together with two small bands migrating at or near the dye front of the gel. The same fragments were observed, albeit faintly, with normal mouse serum. They appeared to be degraded further, generating the bands at or near the front. Incubation with sera from dwarf mice of 8 weeks old generated an additional series of bands which migrated just below the $41 / 44 \mathrm{kDa}$ doublet of the intact IGFBP-3. Pregnancy serum, serum from normal mice or serum from 2-weekold dwarf mice did not induce these bands. We never observed these bands with non-glycosylated IGFBP-3, suggesting that they may be derived from partial deglycosylation of IGFBP-3. Alternatively, glycosylation of the protein makes cleavage sites near the $\mathrm{N}$ terminus or the $\mathrm{C}$ terminus more susceptible to proteolysis.

The amount of intact IGFBP-3 in normal mouse serum (as measured with Western ligand blotting) increases with age (Van Buul-Offers et al. 1994a). Therefore we were interested in determining the IGFBP-3 protease activity during postnatal development in more detail. Figure 2 shows that in normal mice the protease activity declined 


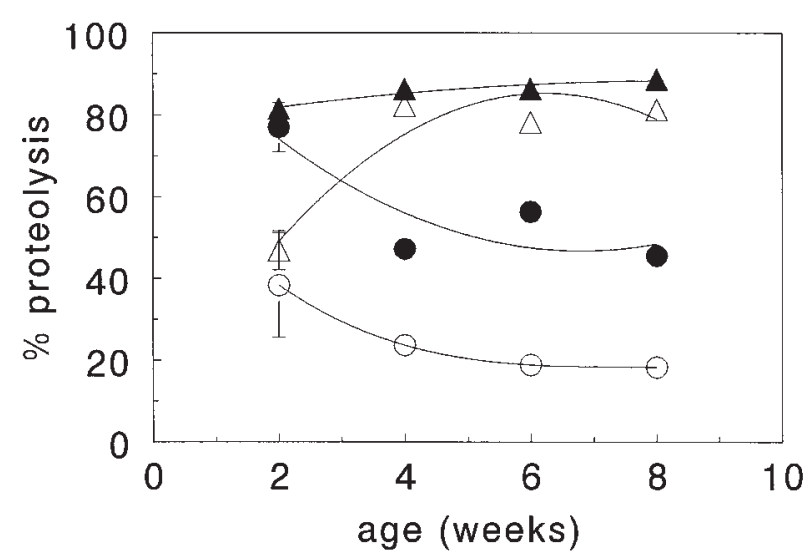

Figure 2 Age-dependent protease activity in sera from normal and dwarf mice. Serum pools from Snell normal $(\bullet, \bigcirc)$ and dwarf mice $(\boldsymbol{\Lambda}, \triangle)$ of different ages were tested for their ability to degrade non-glycosylated IGFBP-3. The amount of proteolysis was determined and expressed as described in Materials and Methods. The closed symbols represent values in the absence of EDTA, the open symbols in the presence of $10 \mathrm{mM}$ EDTA. For the points at 2 weeks old, three different serum pools were tested (each measured once or twice); for the points at 8 weeks old, two different pools were tested (each measured twice); the points at the other ages are single measurements.

with increasing age, while in dwarf mice this activity remained at the same high level throughout the 8-week period tested. However, the ability of EDTA to inhibit the activity in dwarf mice disappeared between 2 and 4 weeks old, indicating that at this age proteases appear which differ from the pregnancy-associated proteases and which are not dependent on divalent cations.

In order to compare further the proteolytic activities in dwarf mice, young normal mice and human pregnancy, we tested various protease inhibitors for their ability to inhibit the proteolytic activity of the respective sera (Fig. 3). EDTA and the $\mathrm{Zn}^{2+}$-chelator phenanthroline as well as the serine protease inhibitors PMSF and aprotinin inhibited the proteolytic activity in human pregnancy serum, consistent with the notion of a divalent cation-dependent serine protease being the enzyme responsible for IGFBP-3 proteolysis in pregnancy (Hossenlopp et al. 1990, Lamson et al. 1991). The inhibition pattern in Snell normal mice was similar, although PMSF seemed less potent than in pregnancy serum, because it could only prevent the formation of the smallest fragments $(<10 \mathrm{kDa})$, while in its presence the intensity of the $18 \mathrm{kDa}$ band was increased. Two-week-old Snell dwarf mice were similar to normal mice with respect to EDTA, PMSF and aprotinin, but the proteolytic activity in this serum was totally unsusceptible to phenanthroline. As in human pregnancy serum, the protease in serum from pregnant mice was inhibited by all four inhibitors tested, including phenanthroline (not shown). This indicates that the inability of phenanthroline to inhibit the protease in dwarf mice is limited to the $\mathrm{GH}$ deficiency state, and is not peculiar to the mouse species. Also at 4 and 8 weeks old, the protease in serum from dwarf mice was unsusceptible to phenanthroline, while in normal mice of these ages, phenanthroline remained inhibitory (not shown).

$\mathrm{GH}$ treatment can partially restore the deficiency in IGFBP-3 in dwarf mice (Van Buul-Offers et al. 1994a,b). We therefore investigated the effect of GH treatment on the protease activity. Figure 4A shows a representative example of the degradation of non-glycosylated and glycosylated IGFBP-3 by sera of PBS- and GH-treated dwarf mice. The results are presented in a quantitative fashion in Fig. 4B. After treatment for 4 weeks, the proteolytic degradation of non-glycosylated IGFBP-3 decreased from
A

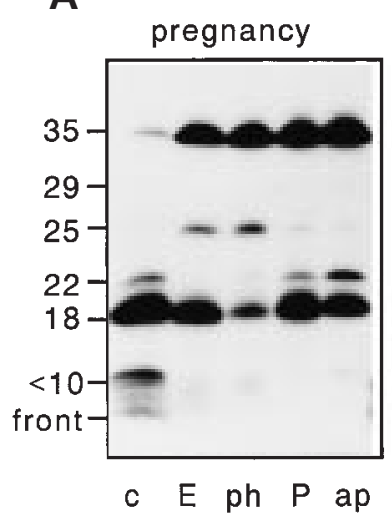

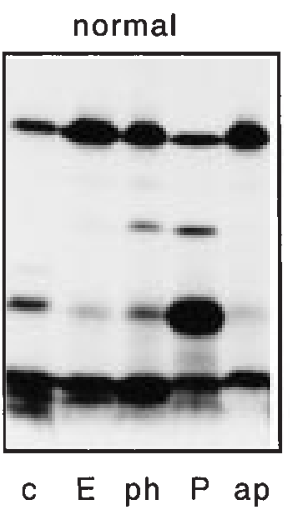

B

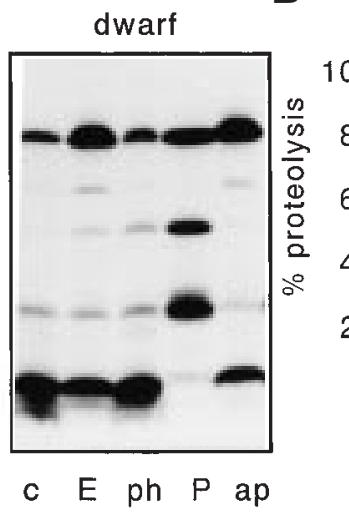

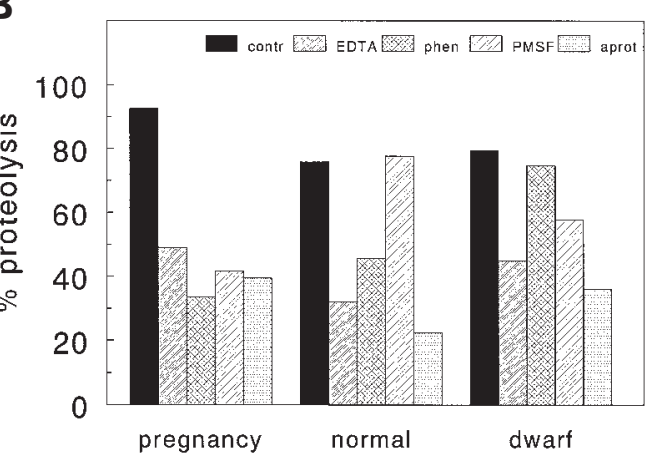

pregnancy normal dwarf

Figure 3 Effect of protease inhibitors. ${ }^{125}$ I-IGFBP-3 (non-glycosylated) was incubated with human pregnancy serum and serum from normal and dwarf Snell mice ( 2 weeks old) in the absence and presence of protease inhibitors. (A) Autoradiograms of a representative experiment. (B) Proteolysis of IGFBP-3, expressed as percentage of IGFBP-3 that appeared as fragments on the gel. Values for pregnancy serum are from one representative experiment. Values for the mouse sera are the means of two separate serum pools, which were each measured once or twice. c, control without inhibitor; E, 10 mM EDTA; ph, 2 mM 1,10-phenanthroline; P, 10 mM PMSF; ap, 2 mg/ml aprotinin. 
A

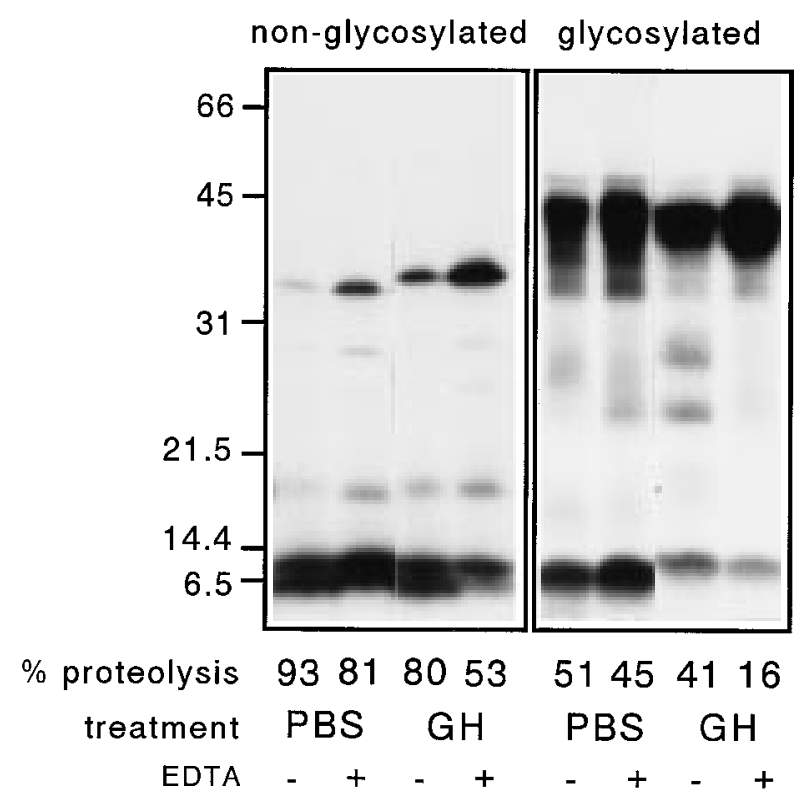

B

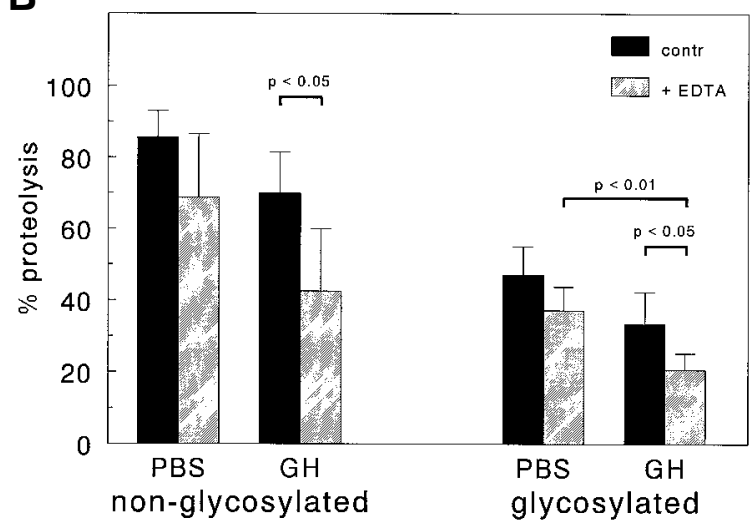

Figure 4 Effect of GH treatment on IGFBP-3-proteolytic activity. Dwarf mice were treated with GH or PBS vehicle as described in Materials and Methods. Proteolytic activities in serum pools (from five animals) were tested with ${ }^{125}$ I-IGFBP-3 (both non-glycosylated and glycosylated) in the absence or presence of $10 \mathrm{mM}$ EDTA. (A) Autoradiogram of a representative gel. (B) Quantitation of proteolytic activities of serum pools from four independent experiments. Proteolysis is expressed as the percentage (mean \pm S.D.) of IGFBP-3 that appeared as fragments on the gel. Each serum pool was measured between one and three times. Statistical significance between groups is indicated by their $P$ value. The molecular masses $(\mathrm{kDa})$ of marker proteins are indicated on the left.

$85 \cdot 5$ to $69 \cdot 9 \%$, a non-significant decrease. Similarly, the assay using glycosylated IGFBP-3 showed proteolysis of 47.0 and $33 \cdot 4 \%$ without and with treatment respectively. This decrease was also not significant. As mentioned above (Fig. 2), the inhibitory effect of EDTA on the protease activity of these (older) dwarf mice was minor, but in the GH-treated animals EDTA could significantly inhibit the protease activity (Fig. 4B). In addition, in the presence of EDTA, GH treatment significantly decreased the proteolysis of glycosylated IGFBP-3 (from $37 \cdot 2$ to $20 \cdot 6 \%$ ). This suggests that during GHD a cation-independent protease is induced, which is largely suppressed by GH treatment.

The pronounced proteolysis in GHD mice is in contrast with the results of Rutishauer et al. (1993) who described a GH-dependent IGFBP-3 protease in rats which was lacking from hypox rats. In order to directly compare hypox rats with dwarf mice, we performed an experiment in which the degradation of both ${ }^{125}$ I-IGFBP-3 tracers was compared for normal and GHD samples of both species. As shown in Fig. 5, hypox rats displayed about twice as much protease activity as normal rats when non-glycosylated IGFBP-3 was used. In contrast with the dwarf mice, the activity in the hypox rats could be well inhibited by EDTA. The activity towards glycosylated IGFBP-3 was negligible (compare with Fig. 1B). This result supports the conclusion reached with the dwarf mice that the protease is induced under conditions of $\mathrm{GH}$ deficiency, and not by GH as was suggested earlier (Rutishauser et al. 1993).

In order to supplement some of the data obtained with radiolabeled IGFBP-3 preparations, we performed mixing experiments with normal human serum as substrate for proteolytic activity. Disappearance of intact IGFBP-3 as visualized by Western immunoblotting (Fig. 6A) was seen for human pregnancy serum and serum from 2-week-old dwarf mice. In both these sera, EDTA inhibited the protease. The amount of proteolysis by dwarf serum (46\% of the endogenous IGFBP-3 in the reference serum) in this system was comparable to proteolysis of glycosylated ${ }^{125}$ I-IGFBP-3 (Fig. 1B), which was $41 \%$. Incubation of reference serum with hypox rat serum resulted in a $49 \%$ decrease in the intensity of the IGFBP-3 doublet as compared with a control incubation with normal rat serum (not shown). Figure 6B shows that also in this system, an age-dependent decrease of protease activity was observed in normal mice (compare with Fig. 2).

\section{Discussion}

In this study we have characterized proteolytic activity for IGFBP-3 in normal mouse serum and in dwarf mouse 


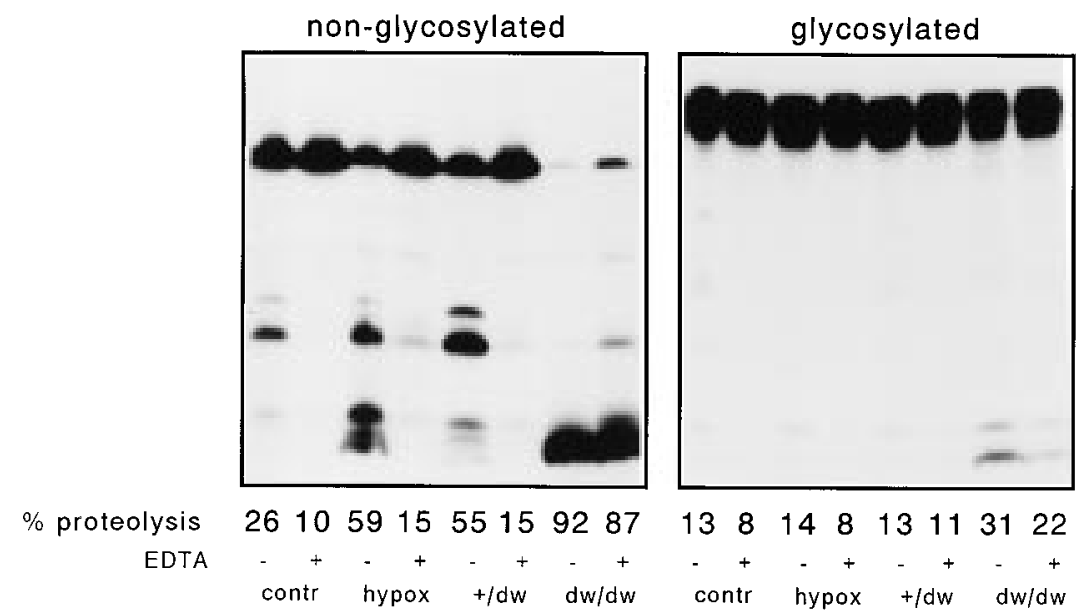

Figure 5 Proteolysis by sera from normal and hypox rats, compared with normal and dwarf mice. ${ }^{125}$ I-IGFBP-3 (non-glycosylated and glycosylated) was incubated with sera from normal rats (contr), hypox rats (hypox), Snell normal mice $(+/ d w)$ and Snell dwarf mice $(d w / d w)$ in the absence or presence of $10 \mathrm{mM}$ EDTA. The mice were 10 weeks old, the rats 5 weeks. Autoradiograms of the gels are shown, together with the percentage of proteolysis. The experiment was repeated once with similar results.

serum. While young normal mice (2 weeks old) showed considerable activity, this declined with age (Figs 1, 2 and $6 \mathrm{~B})$. This correlates with a rise in IGFBP-3 levels as measured by Western ligand blotting (Van Buul-Offers et al. 1994a). In contrast, dwarf mice displayed a strong activity well into adulthood. The results obtained with a protease assay using ${ }^{125}$ I-IGFBP-3 (Lamson et al. 1991) were confirmed when normal serum was used as a source of IGFBP-3 substrate, which was detected by Western ligand blotting.

The proteolytic activity in dwarf mice, especially at later ages, differs in nature from the activity found in young normal mice and in human pregnancy. First, incubation of non-glycosylated IGFBP-3 with serum from dwarf mice resulted in more extensive degradation than with the other sera; only fragments of $<10 \mathrm{kDa}$ remained. Secondly, a characteristic set of degradation bands migrating just below the doublet of glycosylated IGFBP-3 was seen with serum from dwarfs of 4 weeks and older (Fig. 1B shows 8 weeks, but we also observed this pattern at 4 weeks). These bands did not appear when glycosylated IGFBP-3 was degraded by serum from normal mice or pregnant women. Also hypox rat serum generated these bands, although they are only faintly visible on the right panel of Fig. 5. Thirdly, from 4 weeks old onward the proteolytic activity in dwarf serum could not be inhibited by EDTA. While phenanthroline usually inhibits the activity in human pregnancy serum even more strongly than EDTA does, we consistently found no effect of this zinc chelator on the activity in dwarfs (at all ages tested). This is in contrast with most IGFBP-3 proteases described so far, which have been characterized as divalent cation-dependent serine proteases or metalloproteinases (Fielder et al. 1990, Hossenlopp et al.
1990, Cohen et al. 1992, Davenport et al. 1992b, Fowlkes et al. 1994). The only IGFBP-3 proteases which have been described that are not inhibitable by EDTA or phenanthroline are plasmin (Campbell et al. 1992), cathepsin D (Conover \& De Leon 1994) and nerve growth factor (Rajah et al. 1996). The activity in dwarf mice appears to be caused by a mixture of at least two different enzymes since treatment with GH partially restored the inhibitory effect of EDTA. Apparently, GH suppresses the divalent cation-independent enzyme, whereas the total proteolytic activity in the circulation is only minimally altered. There is a striking difference between the inhibitory activity of aprotinin, which largely prevented proteolysis in mouse sera, and PMSF, which prevented the generation of the small $(<10 \mathrm{kDa})$ fragments, while an $18 \mathrm{kDa}$ product accumulated (Fig. 3A). Although both are serine protease inhibitors, their specificities and mechanisms of action differ. In addition, PMSF is labile in aqueous solutions, so proteases which may be activated during the $16 \mathrm{~h}$ incubation period can no longer be inhibited.

GHD rats showed high protease activities already in early pregnancy, while in GH-normal rats protease activity did not occur until late pregnancy (Gargosky et al. 1993). Also the cleavage pattern was slightly different from that produced in late pregnancy. This underscores our finding that in GHD a distinct IGFBP-3 protease is induced. A more detailed study with more specific enzyme inhibitors and/or antibodies will be needed to further characterize the responsible enzyme(s).

The role of GH in the regulation of IGFBP-3 proteases has received limited attention so far. Rutishauer et al. (1993) found proteolytic activity in rat serum, which disappeared upon hypophysectomy. GH treatment restored 


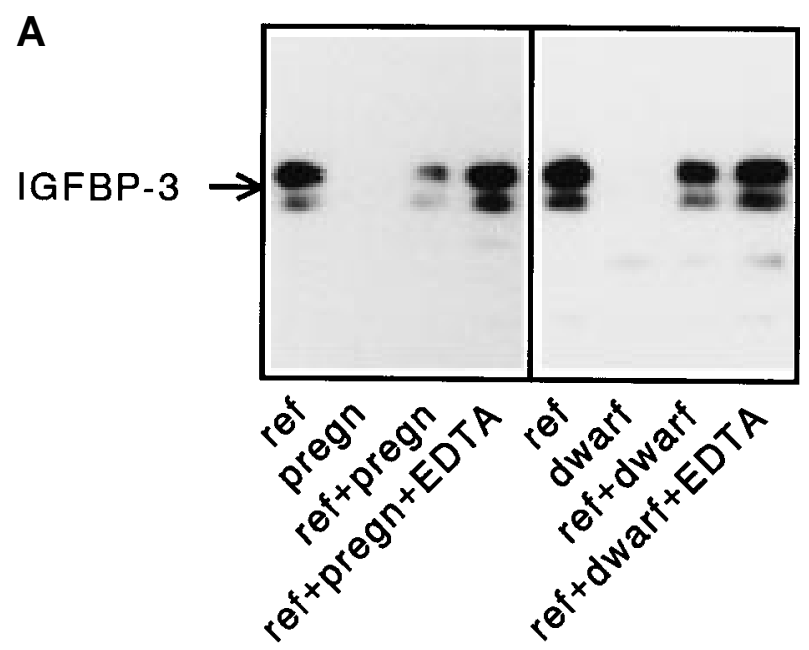

B
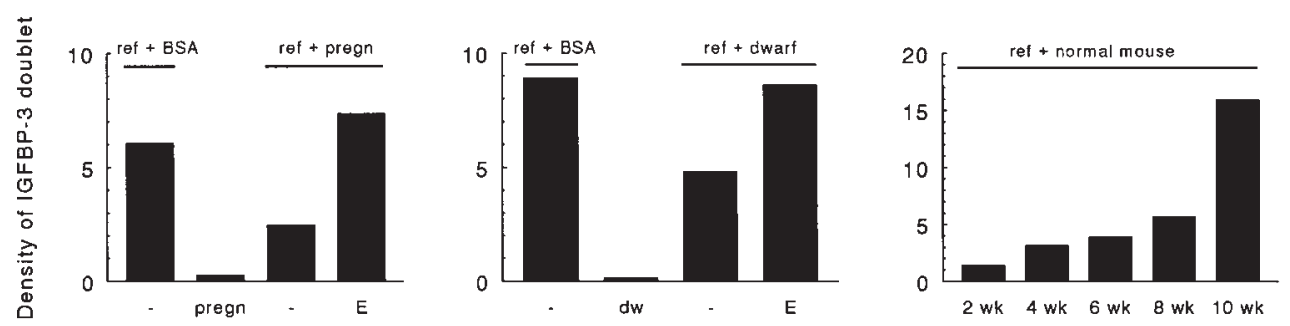

Figure 6 Western ligand blot from mixing experiments. Reference serum (pool of normal human donors) was incubated with human pregnancy serum or mouse serum in the absence or presence of $10 \mathrm{mM}$ EDTA as described in Materials and Methods. (A) Autoradiogram of the Western ligand blots. The mouse serum was from dwarfs of 2 weeks old. (B) Quantitation of the density of the IGFBP-3 doublet (arbitrary units). The left and middle panel correspond to the two panels in (A). The right panel of (B) shows the decline of the proteolytic activity in normal mice with increasing age. ref, ref+BSA, reference serum $(1.6 \mu l)$ incubated with BSA; pregn, pregnancy serum and dwarf, dwarf serum $(0 \cdot 6 \mu \mathrm{l})$ without incubation; E, EDTA (10 mM). The results shown are from a representative experiment. The experiment was repeated with similar results.

the protease activity in hypox rats. These results are in sharp contrast with our findings. Also in experiments in which we used glycosylated ${ }^{125}$ I-IGFBP-3, as Rutishauer et al. (1993) did, or when we compared normal rat serum with hypox rat serum, we consistently found that IGFBP-3 proteolysis is favored under GH-deficient conditions. In analogy to the results with hypox rats (Rutishauser et al. 1993), we found that GH-deficient dwarf mice have very low IGFBP-3 levels as measured by Western ligand blotting, which are increased by GH administration (Van Buul-Offers et al. 1994a,b). An increase in protease activity, as reported by Rutishauer et al. (1993) would instead be expected to lead to a decrease of IGFBP-3 as measured by this method, because partially proteolyzed IGFBP-3 cannot be detected by this method (Gargosky et al. 1992, Liu et al. 1992). At this time, we cannot reconcile the discrepancies between our results and those of Rutishauer et al. (1993). It is evident, however, that differences exist between the hypox rat and dwarf mouse models. GH treatment can restore IGFBP-3 to normal levels in hypox rats (Rutishauser et al. 1993, Fielder et al. 1996), while it only partially restores IGFBP-3 in dwarf mice (Van Buul-Offers et al. 1994a,b). Furthermore, our results (Fig. 5) indicate that the IGFBP-3 protease activity in the hypox rat serum is lower than in the dwarf mouse serum and can be better inhibited by EDTA.

Our results with dwarf mice appear to correlate better with a study in which $\mathrm{GH}$-deficient patients were compared with normal controls (Binoux et al. 1993). IGFBP-3 in the patient serum was proteolyzed to a greater extent $(53 \%)$ than in the controls (37\%).

It remains an open question why GH treatment only has a limited effect on the protease activity in dwarf mice. As mentioned earlier, also IGF-I and IGFBP-3 levels are only minimally elevated (Van Buul-Offers et al. 1994a,b). Also the $150 \mathrm{kDa}$ complex of IGFBP-3 with IGF-I and ALS is not restored (Van Buul-Offers et al. 1994a). The effects of 
GH treatment on growth pattern (Van Buul-Offers \& Van den Brande 1978, Van Buul-Offers et al. 1994a,b) and growth plate morphology (Smeets \& Van Buul-Offers 1983) are much more pronounced, however, suggesting that paracrine or autocrine actions of locally induced IGF-I prevail. Others have also reported $\mathrm{GH}$-induced stimulation of growth in hypox rats (Orlowski \& Chernausek 1988) and Snell dwarf mice (Pell \& Bates 1992) while circulating IGF-I levels were not or only modestly increased. It appears that administration of $\mathrm{GH}$ by continuous infusion restores circulating concentrations of IGF-I and IGFBP-3 much better than administration by twice-daily injections does (Gargosky et al. 1994). It would therefore be of interest to determine if also the IGFBP-3 protease activity decreases more after continuous administration. In addition, the proposed local actions of $\mathrm{GH}$ warrant study of the regulation of IGFBP-3 proteases at the cellular level.

Taken together, our results suggest that in GH deficiency a complex protease system is present that results in cleavage of IGFBP-3. Presumably, this leads to release of IGF-I and/or IGF-II from the $150 \mathrm{kDa}$ ternary complex, making these growth factors available for binding to the type I IGF receptor. This mechanism resembles the enhanced availability of IGF-I through IGFBP-3 degradation in other catabolic states such as pregnancy (Blat et al. 1994), chronic renal failure (Lee et al. 1993), insulindependent (Bereket et al. 1995) and non-insulindependent diabetes mellitus (Bang et al. 1994), and severe illness (Davies et al. 1991). In the same context, prostate specific antigen is an IGFBP-3 protease which potentiates IGF action (Cohen et al. 1994). Similarly, IGFBP-3 proteases have been suggested to play a role in tumor progression by allowing IGF-I to exert its mitogenic actions on tumor cells (Muller et al. 1994). Clearly, proteolysis of IGFBPs and in particular IGFBP-3 is an important defense mechanism and therefore further investigations into its nature and regulation are certainly warranted.

\section{References}

Bang P, Brismar K \& Rosenfeld RG 1994 Increased proteolysis of insulin-like growth factor-binding protein-3 (IGFBP-3) in noninsulin-dependent diabetes mellitus serum, with elevation of a 29-kilodalton (kDa) glycosylated IGFBP-3 fragment contained in the approximately $130-$ to $150-\mathrm{kDa}$ ternary complex. Journal of Clinical Endocrinology and Metabolism 78 1119-1127.

Baxter RC 1994 Insulin-like growth factor binding proteins in the human circulation: A review. Hormone Research 42 140-144.

Baxter RC \& Martin JL 1986 Radioimmunoassay of growth hormone-dependent insulin-like growth factor binding protein in human plasma. Journal of Clinical Investigation 78 1504-1512.

Bereket A, Lang CH, Blethen SL, Fan J, Frost RA \& Wilson TA 1995 Insulin-like growth factor binding protein-3 proteolysis in children with insulin-dependent diabetes mellitus: A possible role for insulin in the regulation of IGFBP-3 protease activity. Journal of Clinical Endocrinology and Metabolism 80 2282-2288.
Binoux M, Lalou C, Lassarre C, Blat C \& Hossenlopp P 1993 Limited proteolysis of insulin-like growth factor binding protein-3 (IGFBP-3): A physiological mechanism in the regulation of IGF bioavailability. Advances in Experimental and Medical Biology 343 293-300.

Blat C, Villaudy J \& Binoux M 1994 In vivo proteolysis of serum insulin-like growth factor (IGF) binding protein-3 results in increased availability of IGF to target cells. Journal of Clinical Investigation 93 2286-2290.

Blum WF, Ranke MB, Kietzmann K, Gauggel E, Zeisel HJ \& Bierich JR 1990 A specific radioimmunoassay for the growth hormone $(\mathrm{GH})$-dependent somatomedin-binding protein: Its use for diagnosis of GH deficiency. Journal of Clinical Endocrinology and Metabolism 70 1292-1298.

Campbell PG, Novak JF, Yanosick TB \& McMaster JH 1992 Involvement of the plasmin system in dissociation of the insulin-like growth factor-binding protein complex. Endocrinology $\mathbf{1 3 0}$ 1401-1412.

Cohen P, Graves HCB, Peehl DM, Kamarei M, Giudice LC \& Rosenfeld RG 1992 Prostate-specific antigen (PSA) is an insulin-like growth factor binding protein-3 protease found in seminal plasma. Journal of Clinical Endocrinology and Metabolism $\mathbf{7 5}$ 1046-1053.

Cohen P, Peehl DM, Graves HCB \& Rosenfeld RG 1994 Biological effects of prostate specific antigen as an insulin-like growth factor binding protein-3 protease. Journal of Endocrinology 142 407-415.

Conover CA \& De Leon DD 1994 Acid-activated insulin-like growth factor-binding protein-3 proteolysis in normal and transformed cells. Role of cathepsin D. Journal of Biological Chemistry 269 7076-7080.

Coulson VJ, Macaulay JAH, Wass JAH \& Holly JMP 1991 The presence of a circulating protease for IGF binding protein 3 (IGFBP-3) in patients with cancer of the lung, breast, or head and neck. Journal of Endocrinology 131 (Suppl) Abstract 50.

Cwyfan Hughes SC, Cotterill AM, Molloy AR, Cassell TB, Braude N, Hinds CJ, Wass JAH \& Holly JMP 1992 The induction of specific proteases for insulin-like growth factor-binding proteins following major heart surgery. Journal of Endocrinology 135 135-145.

Davenport ML, Clemmons DR, Miles MV, Camacho-Hubner C, D'Ercole AJ \& Underwood LE 1990 Regulation of serum insulin-like growth factor-I (IGF-I) and IGF binding proteins during rat pregnancy. Endocrinology 127 1278-1286.

Davenport ML, Isley WL, Pucilowska JB, Pemberton LB, Lyman B, Underwood LE \& Clemmons DR 1992a Insulin-like growth factor-binding protein-3 proteolysis is induced after elective surgery. Journal of Clinical Endocrinology and Metabolism 75 590-595.

Davenport ML, Pucilowska J, Clemmons DR, Lundblad R, Spencer JA \& Underwood LE $1992 b$ Tissue-specific expression of insulin-like growth factor binding protein-3 protease activity during rat pregnancy. Endocrinology 130 2505-2512.

Davies SC, Wass JAH, Ross RJM, Cotterill AM, Buchanan CR, Coulson VJ \& Holly JMP 1991 The induction of a specific protease for insulin-like growth factor binding protein-3 in the circulation during severe illness. Journal of Endocrinology 130 469-473.

Fielder PJ, Thordarson G, Talamantes F \& Rosenfeld RG 1990 Characterization of insulin-like growth factor binding proteins (IGFBPs) during gestation in mice: Effects of hypophysectomy and an IGFBP-specific serum protease activity. Endocrinology 127 2270-2280.

Fielder PJ, Mortensen DL, Mallet P, Carlsson B, Baxter RC \& Clark RG 1996 Differential long-term effects of insulin-like growth factor-I (IGF-I), growth hormone (GH), and IGF-I plus GH on body growth and IGF binding proteins in hypophysectomized rats. Endocrinology 137 1913-1920.

Fowlkes JL, Suzuki K, Nagase H \& Thrailkill KM 1994 Proteolysis of insulin-like growth factor binding protein-3 during rat pregnancy: A role for matrix metalloproteinases. Endocrinology 135 2810-2813.

Gargosky SE, Pham HM, Wilson KF, Liu F, Giudice LC \& Rosenfeld RG 1992 Measurement and characterization of 
insulin-like growth factor binding protein-3 in human biological fluids: Discrepancies between radioimmunoassay and ligand blotting. Endocrinology 131 3051-3060.

Gargosky SE, Nanto-Salonen K, Tapanainen P \& Rosenfeld RG 1993 Pregnancy in growth hormone-deficient rats: Assessment of insulin-like growth factors (IGFs), IGF-binding proteins (IGFBPs) and IGFBP protease activity. Journal of Endocrinology 136 479-489.

Gargosky SE, Tapanainen P \& Rosenfeld RG 1994 Administration of growth hormone $(\mathrm{GH})$, but not insulin-like growth factor-I (IGF-I), by continuous infusion can induce the formation of the 150-kilodalton IGF-binding protein-3 complex in GH-deficient rats. Endocrinology 134 2267-2276.

Giudice LC, Farrell EM, Pham H, Lamson G \& Rosenfeld RG 1990 Insulin-like growth factor binding proteins in maternal serum throughout gestation and in the puerperium: Effects of a pregnancy-associated serum protease activity. Journal of Clinical Endocrinology and Metabolism 71 806-816.

Hossenlopp P, Seurin D, Segovia-Quinson B, Hardouin S \& Binoux M 1986 Analysis of serum insulin-like growth factor binding proteins using western blotting: use of the method for titration of the binding proteins and competitive binding studies. Analytical Biochemistry 154 138-143.

Hossenlopp P, Segovia B, Lassarre C, Roghani M, Bredon M \& Binoux M 1990 Evidence of enzymatic degradation of insulin-like growth factor-binding proteins in the $150 \mathrm{~K}$ complex during pregnancy. Journal of Clinical Endocrinology and Metabolism 71 $797-805$.

Jones JI \& Clemmons DR 1995 Insulin-like growth factors and their binding proteins: Biological actions. Endocrine Reviews 16 3-34.

Lamson G, Giudice LC \& Rosenfeld RG 1991 A simple assay for proteolysis of IGFBP-3. Journal of Clinical Endocrinology and Metabolism 72 1391-1393.

Lee DY, Cohen P, Krensky AM, Rosenfeld RG \& Yorgin PD 1993 Insulin-like growth factor binding protein-3 protease activity in the urine of children with chronic renal failure. Pediatric Nephrology 7 416-423.

Li S, Crenshaw EB III, Rawson EJ, Simmons DM, Swanson LW \& Rosenfeld MG 1990 Dwarf locus mutants lacking three pituitary cell types result from mutations in the POU-domain gene pit-1. Nature 347 528-533.

Liu F, Baxter RC \& Hintz RL 1992 Characterization of the high molecular weight insulin-like growth factor complex in term pregnancy serum. Journal of Clinical Endocrinology and Metabolism 75 1261-1267.

Muller HL, Oh Y, Gargosky SE, Wilson KF, Lehrnbecher T \& Rosenfeld RG 1994 Insulin-like growth factor binding protein-3 concentrations and insulin-like growth factor binding protein-3 protease activity in sera of patients with malignant solid tumors or leukemia. Pediatric Research 35 720-724.

Orlowski CC \& Chernausek SD 1988 Discordance of serum and tissue somatomedin levels in growth hormone-stimulated growth in the rat. Endocrinology 123 44-49.

Pell JM \& Bates PC 1992 Differential actions of growth hormone and insulin-like growth factor-I on tissue protein metabolism in dwarf mice. Endocrinology 130 1942-1950.
Rajah R, Bhala A, Nunn SE, Peehl DM \& Cohen P 1996 7S nerve growth factor is an insulin-like growth factor-binding protein protease. Endocrinology 137 2676-2682.

Rutishauser J, Schmid C, Hauri C, Froesch ER \& Zapf J 1993 Growth hormone, but not insulin-like growth factor I, induces a serum protease activity for insulin-like growth factor binding protein-3 in hypophysectomized rats in vivo. FEBS Letters 334 23-26.

Shimasaki S \& Ling N 1991 Identification and molecular characterization of insulin-like growth factor binding proteins (IGFBP-1, -2, -3, -4, -5 and 6). Progress in Growth Factor Research 3 243-266.

Smeets T \& Van Buul-Offers SC 1983 The influence of growth hormone, somatomedins, prolactin and thyroxine on the morphology of the proximal tibial epiphysis and growth plate of Snell dwarf mice. Growth 47 160-173.

Sommer A, Maack CA, Spratt SK, Mascarenhas D, Tressel TJ, Rhodes ET, Lee R, Roumas M, Tatsuno GP, Flynn JA, Gerber N, Taylor J, Cudny H, Nanney L, Hunt TK \& Spencer EM 1991 Molecular genetics and actions of recombinant insulin-like growth factor binding protein-3. In Modern Concepts of Insulin-like Growth Factors, pp 715-728. Ed. EM Spencer. New York: Elsevier.

Tressel TJ, Tatsuno GP, Spratt K \& Sommer A 1991 Purification and characterization of human recombinant insulin-like growth factor binding protein 3 expressed in Chinese hamster ovary cells. Biochemical and Biophysical Research Communications 178 625-633.

Van Buul-Offers SC 1983 Hormonal and other inherited growth disturbances in mice with special reference to the Snell dwarf mouse. A review. Acta Endocrinologica 103 (Suppl 258) 1-47.

Van Buul-Offers SC \& Van den Brande JL 1978 The Snell-dwarf mouse I. General growth pattern, before and during growth hormone and thyroxine therapy. Acta Endocrinologica 89 632-645.

Van Buul-Offers SC, Ueda I \& Van den Brande JL 1986 Biosynthetic somatomedin-C (SM-C/IGF-I) increases the length and weight of Snell dwarf mice. Pediatric Research 20 825-827.

Van Buul-Offers SC, Bloemen RJ, Reijnen-Gresnigt MG, Van Leiden HA, Hoogerbrugge CM \& Van den Brande JL 1994a Insulin-like growth factor I and II and their binding proteins during postnatal development of dwarfed Snell mice before and during growth hormone and thyroxine therapy. Journal of Endocrinology 143 191-198.

Van Buul-Offers SC, Reijnen-Gresnigt MG, Hoogerbrugge CM, Bloemen RJ, Kuper CF \& Van den Brande JL $1994 b$ Recombinant insulin-like growth factor-II inhibits the growth-stimulating effect of growth hormone on the liver of Snell dwarf mice. Endocrinology 135 977-985.

Van Buul-Offers SC, De Haan K, Reijnen-Gresnigt MG, Meinsma D, Jansen M, Oei SL, Bonte EJ, Sussenbach JS \& Van den Brande JL 1995 Overexpression of human IGF-II in transgenic mice causes increased growth of the thymus. Journal of Endocrinology 144 491-502.

Received 29 September 1997 Accepted 22 December 1997 